Science, Technology and Development 35 (2): 82-87, 2016

ISSN 0254-6418 / DOI: 10.3923/std.2016.82.87

(C) 2016 Pakistan Council for Science and Technology

\title{
Agroeconomic Evaluation of Late Sown Wheat (Pak-13) for Nutrient Ratios and Seeding Densities under Rainfed Conditions
}

\author{
${ }^{1}$ Syed Haider Abbas, ${ }^{2}$ Ayesha Tahir, ${ }^{3}$ Saira Batool, ${ }^{1}$ Maqsood Qamar, \\ ${ }^{1}$ Muhammad Sohail and ${ }^{1}$ Sikander Khan Tanveer \\ ${ }^{1}$ Wheat Program, CSI, National Agricultural Research Centre, Islamabad, Pakistan \\ ${ }^{2}$ Planning, Monitoring and Evaluation Division, Pakistan Agricultural Research Council, \\ Islamabad, Pakistan \\ ${ }^{3}$ Social Sciences Research Institute, National Agricultural Research Centre, Islamabad, Pakistan
}

\begin{abstract}
Breeding in wheat crop for improvement in new varieties having high yield, besides desirable and durable disease resistance is a continuous and long-term process and if it is coupled with better agro economic traits evaluation, there can be a clearer picture about the performance of newly developed cultivar in any crop species. A field study was conducted at the Research Farm Area of National Agricultural Research Centre, Islamabad, in wheat program during 2014-15, under late sown conditions. It was a 'Randomized Complete Block Desig'n with split plot arrangement, having fertilizer ratios in main plots and seeding densities in subplots. Both fertilizer ratios and seeding densities had four levels. From the analyzed data, it was revealed that under late sown circumstances, different nutrient ratios were statistically different in chlorophyll contents, number of tillers $\left(\mathrm{m}^{-2}\right)$ and biological yield $\left(\mathrm{kg} \mathrm{ha}^{-1}\right)$, whereas, it was at par for plant height, spike length, leaf area and grain yield $\left(\mathrm{kg} \mathrm{ha}^{-1}\right)$. It was also revealed that there were 22 and $21 \%$ higher tillers $\mathrm{m}^{-2}$ and biological yield $\left(\mathrm{kg} \mathrm{ha}^{-1}\right)$, as compared to those conditions when there was no fertilizer application in the soil. In case of various seeding densities, a significant response was found for number of tillers $\left(\mathrm{m}^{-2}\right)$, biological yield $\left(\mathrm{kg} \mathrm{ha}^{-1}\right)$ and grain yield $\left(\mathrm{kg} \mathrm{ha}^{-1}\right)$. In case of interaction of nutrient ratios with seeding densities, a significant response was found only in biological yield $\left(\mathrm{kg} \mathrm{ha}^{-1}\right)$ at F3 $\left(90: 60 \mathrm{~N} \mathrm{P} \mathrm{kg} \mathrm{ha}^{-1}\right) \times \mathrm{SD} 4\left(140 \mathrm{~kg} \mathrm{ha}^{-1}\right)$. While considering the benefit cost ratio (BCR) for nutrient ratios, it was found maximum at 45:30 level (F2) which was 1:8.45. In case of seeding densities, maximum BCR was observed in $80 \mathrm{~kg} \mathrm{ha}^{-1}$ (1:17.61).
\end{abstract}

Key words: Wheat, late sowing, nutrient ratios, seeding densities, benefit cost ratio

\section{INTRODUCTION}

Incidence of disease attack, breeding for high yielding wheat cultivars, coupled with modern biotechnological techniques, is going side by side since a time ago. Wheat is the Pakistan's major food crop, which is feeding the whole nation. Wheat contribution to the value added in agriculture and gross domestic production was 10 and $2.1 \%$, respectively. The production of wheat stood at 25.478 million tonnes during 2014-15 (GoP., 2014-15). Wheat yield is low in Pakistan, as compared to other countries, due to many biotic and abiotic reasons, including the time of sowing and planting density, which are of great importance, deciding the appropriate stand establishment of the growing crop through harmonizing the plant to plant contest and ultimately affect the yield (Kabesh et al., 2009; Nakano and Morita, 2009).

Among the several factors, responsible for low yield in Pakistan, the use of unbalanced rate of fertilizers and wrong seed rates are important and exploration on these limiting factors on newly released cultivars will surely lead to high returns. Optimum seed rate is important for maximum yield and return for the crop. If higher seed rate is used, the plant population will be higher and there will be competition among plants for water, nutrients and sunlight which, in turn, may lead to low quality and low yield. If fewer seed rate is used, the yield will be less, due to lesser number of plants per unit area (Hameed et al., 2003). Khan et al. (2002) reported that maximum grain yield was achieved with high seed rate, while minimum grain yield was obtained by low seed rate. "Optimum seeding density is an important management tool for improving yield of wheat. It is of scrupulous importance in wheat production because it is under a farmer's control in most cropping systems (Slafer and Satorre, 1999)." Optimum plant densities vary significantly between areas, climatic conditions, soil, sowing time and varieties. Seeding density is one of the prime determinants, which shows the ability of the crop to detain resources. There has been considerable focus on defining the relationship 
between density and crop yield quantitatively in order to establish optimum populations and maximum reasonable yield under various situations. As a result, the effect of density on wheat plant size and crop productivity has received significant importance (Harper, 1977).

The judicious use of fertilizers can contribute to yield increments. Nitrogen (N) and Phosphorous (P) are the main important plant food nutrients and most of the soils are lacking in these nutrients (Ahmad et al., 1999). The balanced use of $\mathrm{N}$ and $\mathrm{P}$ fertilizers is of significant importance in wheat production and their use in optimum share at appropriate time has a vital role on wheat yield. Plant species, even varieties within species, differ in their manners to acquire and utilize $\mathrm{N}$ and $\mathrm{P}$ for grain production (Ahmad et al., 1992; Gill et al., 1994). Mazurek and Kus (1991) reported that under late sown conditions having higher $\mathrm{N}$ rates reduced 1,000 grain weight, increased lodging and disease incidences besides improving protein yield and grain protein. Increase in cropping intensity and introduction of high yielding varieties have caused considerable decrease of $\mathrm{N}$ and crop storage positive response to added $\mathrm{N}$ in the soil (Ali et al., 2004). "Nitrogen plays an imperative role in growth processes as it is an integral part of chlorophyll, protein and nucleic acid (Marschner, 1995; Jabbar et al., 2009).” It is viewed as the central element because of its role in substance synthesis (Akhtar et al., 1999). It constitutes 1.5-5 percent of the dry weight of higher plants (Novoa and Loomis, 1981). "Phosphorous scarcity is common in most of the soils of Pakistan and application of phosphatic fertilizer is considered crucial for crop production and motivates flourishing and seed formation (Memon, 1996)." Timely sowing of wheat crop in rainfed conditions is of prime importance as it contributes in gaining optimum grain yield as delay in planting, due to unavoidable weather conditions or due to delay in harvesting of previous crop, causes $10-15 \mathrm{~kg}$ reduction in yield on daily basis. So plant breeders must focus for breeding such type of varieties, which can perform better in late sown conditions besides performing well in normal planting windows already set by the scientists.

Keeping in view the prime importance of increasing fertilizer rates and cost of seeds in late sown conditions, the study was aimed to investigate the optimum equilibrium level of nutrient levels, seeding densities and BCR as due to changing climatic conditions sowing patterns need to be revisited.

\section{MATERIALS AND METHODS}

Optimum use of $\mathrm{N}$ and $\mathrm{P}$ fertilizers is the need of time in order to save resources under diminishing soil, energy and environmental conditions. Similarly, a good crop stand can lead to get high returns in terms of grain yield and benefit cost ratio (BCR). A field study was planned and executed at Research Farm Area of National Agricultural Research Centre, Islamabad $\left(33^{\circ} 42^{\prime} \mathrm{N}, 73^{\circ} 10^{\prime} \mathrm{E}\right)$ allotted to Wheat Program, during 2014-15. It was Randomized Complete Block Design, having split plot arrangements of treatments. Following treatments were used to achieve the targets.

\begin{tabular}{lc}
\hline Nutrient ratio kg ha ${ }^{-1}$ (Main plots) & Seeding density kg ha ${ }^{-1}$ (Sub plots) \\
\hline F1 $=$ Control $(\mathrm{N}: \mathrm{P}=0)$ & $\mathrm{SD} 1=80$ \\
$\mathrm{~F} 2=45: 30$ & $\mathrm{SD} 2=100$ \\
$\mathrm{~F} 3=90: 60$ & $\mathrm{SD} 3=120$ \\
$\mathrm{~F} 4=135: 90$ & $\mathrm{SD} 4=140$ \\
\hline
\end{tabular}

It was replicated three times and the main plot was $6 \times 5 \mathrm{~m} 2$ and the subplot was $1.5 \times 5 \mathrm{~m}^{2}$. A newly developed wheat cultivar 'Pakistan 2013' was assorted under different treatment regimes. It was sown late in the 3rd week of December to evaluate its performance in relation to nutrient ratios and seeding densities. Before sowing of the crop, soil properties were also measured with standard sampling techniques. During the course of study, various traits, like plant height $(\mathrm{cm})$, spike length $(\mathrm{cm})$, chlorophyll contents (with the help of chlorophyll meter), leaf area, number of tillers $\mathrm{m}^{-2}$, biological yield $\left(\mathrm{kg} \mathrm{ha}^{-1}\right)$ and grain yield $\left(\mathrm{kg} \mathrm{ha}^{-1}\right)$ were taken. Following procedures were used for taking the data on individual parameter of the crop. Four middle rows were harvested, they were air dried and weighed to record biological yield, which was converted on per hectare basis. Four rows were harvested for grain yield and threshed. After threshing, the grains were cleaned, dried and weighed to record the grain yield and were finally analyzed in Statistix Statistical software at 5\% alpha level as described by Steel et al. (1997).

\section{RESULTS AND DISCUSSION}

Agroclimatic conditions (2014-15): The climatic conditions for the reported season under study are summarized in Fig. 1. Seasonal rainfall was $663.93 \mathrm{~mm}$. The maximum rainfall was noted in the month of March (306.53 mm). The air temperature was normal during the season. Maximum air temperature of October 2014, November, December, January 2015, February, March and April, 2015 were 28.0, 24.6, 20, 23, 19.4, 22 and $27.5^{\circ} \mathrm{C}$, respectively. The maximum average temperature was recorded in the month of April $\left(27.5^{\circ} \mathrm{C}\right)$. The minimum average temperature was observed in the month of December $\left(2.77^{\circ} \mathrm{C}\right)$. Average relative humidity from October, 2014 to April, 2015 varied from 68-78\% and maximum was noted in the month of February, 2015, i.e., 78\%. Wind speed during the reported season varied 
from 20.2-37.5 $\mathrm{km} \mathrm{day}^{-1}$ and maximum was in the month of January, i.e., 37.5. Evapotranspiration was maximum in the month of April, 2015 (115.5 mm), whereas the lowest was noted in the month of December, 2014 (38.6 mm).

Soil profile status: Soil sampling was done before sowing of the crop and the data is given in Table 1.

Nutrient ratios: It is evident from Table 2, that varying nutrient ratios had no significant effect on plant height. The highest was noted in $\mathrm{F} 4$ level having $88 \mathrm{~cm}$, whereas the lowest was recorded in control $(85.85 \mathrm{~cm})$. These results are in contrast with the findings of Malghani et al. (2010), they reported that there was significant effect of various nutrient ratios on plant height of wheat. In

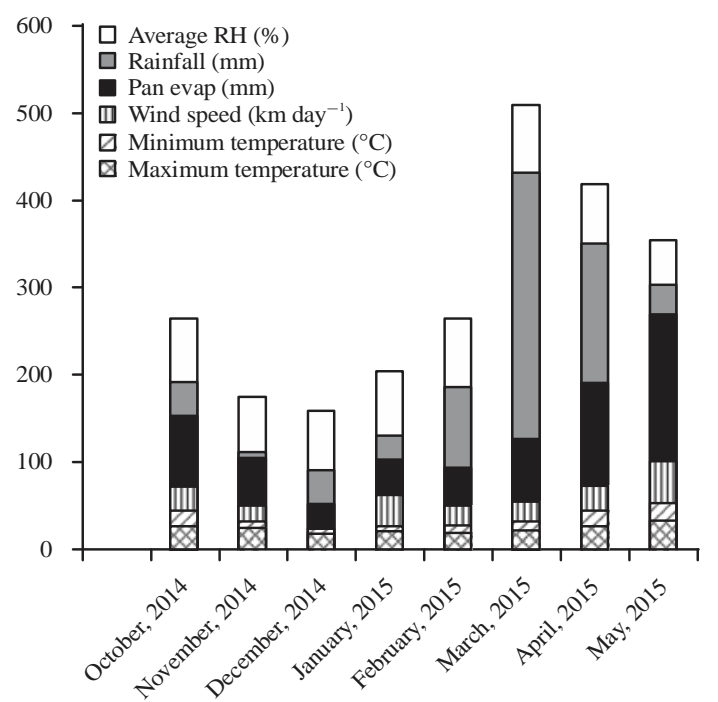

Fig. 1: Agroclimatic conditions during crop season (2014-15)

Table 1: Soil status of NARC, wheat-land area (2014)

\begin{tabular}{ll}
\hline Parameters & Value \\
\hline Soil texture & Loam \\
$\mathrm{pH}$ & 7.79 \\
$\mathrm{OM}$ & $0.5 \%$ \\
Phosphorus & $6.4 \mathrm{mg} \mathrm{kg}^{-1}$ \\
Potassium & $100 \mathrm{mg} \mathrm{kg}^{-1}$ \\
Nitrogen & $0.025 \%$ \\
TOC & $0.29 \%$ \\
\hline
\end{tabular}

Table 2, it was shown that varying nutrient ratios had no significant effect on the spike length. The highest length was noted in F4 level, having $11.35 \mathrm{~cm}$, whereas, the lowest was recorded in control $(11.042 \mathrm{~cm})$. These results are contrary to the findings of Laghari et al. (2010), who concluded that various fertilizer rates had significant effect on spike length in wheat cultivars. Further, varying nutrient ratios had significant effect on chlorophyll contents. The highest was noted in F3 level, having 54.125, whereas the lowest was recorded in control (51.09). From Table 2, it was shown that varying nutrient ratios had no significant effect on leaf area. The highest was noted in F4 level, having $33.55 \mathrm{~cm}^{2}$, whereas the lowest was recorded in control $\left(31.56 \mathrm{~cm}^{2}\right)$. From Table 2, it was shown that varying nutrient ratios had significant effect on number of tillers $\mathrm{m}^{-2}$. The highest was noted in F4 level, having 304, whereas the lowest was recorded in control (235). These findings are in line with the results of Niamatullah et al. (2011) and Tahir et al. (2004); they reported that application of various levels of fertilizers significantly increased the number of tillers $\mathrm{m}^{-2}$. This might be due to increased nitrogen ratios, therefore, promoted greater stimulation of vegetative growth. All fertilizer levels had significant effect on vegetative growth of the plant depending upon the accessibility of the required nutrients, which leads to relative increase in tillers $\mathrm{m}^{-2}$.

Varying nutrient ratios had significant effect on biological yield $\left(\mathrm{kg} \mathrm{ha}^{-1}\right)$. The highest was noted in F4 level, having $6625 \mathrm{~kg} \mathrm{ha}^{-1}$, whereas the lowest was recorded in control (5208). High level of nitrogen promoted vegetative growth. These findings are in line with the work of Niamatullah et al. (2011), Tahir et al. (2004) and Laghari et al. (2010), they reported that varying fertilizer regimes had significant impact on biological yield $\left(\mathrm{kg} \mathrm{ha}^{-1}\right)$ in wheat. The increase in biological yield with the increase in N, P levels may be due to the effect of nitrogen on vegetative growth of wheat as well as increase in tillers' number with higher rates of nitrogen. In Table 2, it was shown that varying nutrient ratios had no significant effect. The highest was noted in F3 level, having $1841 \mathrm{~kg} \mathrm{ha}^{-1}$, whereas the lowest was recorded in control (1548). These findings are in contrast with the work of Niamatullah et al. (2011),

Table 2: Table of means showing nutrients ratios

\begin{tabular}{lccccccc}
\hline $\begin{array}{l}\text { Nutrient ratio } \\
\left(\mathrm{kg} \mathrm{ha}^{-1}\right)\end{array}$ & $\begin{array}{l}\text { Plant height } \\
(\mathrm{cm})\end{array}$ & $\begin{array}{l}\text { Spike length } \\
(\mathrm{cm})\end{array}$ & $\begin{array}{l}\text { Chlorophyll } \\
\text { content }\end{array}$ & Leaf area $\left(\mathrm{cm}^{2}\right)$ & $\begin{array}{l}\text { No. of } \\
\text { tillers }\left(\mathrm{m}^{-2}\right)\end{array}$ & $\begin{array}{l}\text { Biological yield } \\
\left(\mathrm{kg} \mathrm{ha}^{-1}\right)\end{array}$ & $\begin{array}{l}\text { Grain yield } \\
\left(\mathrm{kg} \mathrm{ha}^{-1}\right)\end{array}$ \\
\hline F1 = 0 0 & 85.858 & 11.042 & $51.092^{\mathrm{B}}$ & 31.565 & $235.25^{\mathrm{B}}$ & $5208.3^{\mathrm{C}}$ & 1548.3 \\
F2 $=4530$ & 86.375 & 11.046 & $53.783^{\mathrm{A}}$ & 32.190 & $255.58^{\mathrm{AB}}$ & $5708.3^{\mathrm{BC}}$ & 1642.5 \\
F3 $=9060$ & 87.117 & 11.255 & $54.125^{\mathrm{A}}$ & 33.988 & $269.75^{\mathrm{AB}}$ & $6250.0^{\mathrm{AB}}$ & 1840.8 \\
F4 = 135 90 & 88.008 & 11.358 & $52.492^{\mathrm{AB}}$ & 34.554 & $303.50^{\mathrm{A}}$ & $6625.0^{\mathrm{A}}$ & 1712.5 \\
LSD at 5\% level & NS & NS & 2.4891 & NS & 49.437 & 747.76 & NS \\
\hline
\end{tabular}


Sci. Technol. Dev., 35 (2): 82-87, 2016

Table 3: Table of means having various seeding densities

\begin{tabular}{lccccccc}
\hline $\begin{array}{l}\text { Seeding density } \\
\left(\mathrm{kg} \mathrm{ha}^{-1}\right)\end{array}$ & $\begin{array}{l}\text { Plant height } \\
(\mathrm{cm})\end{array}$ & $\begin{array}{l}\text { Spike length } \\
(\mathrm{cm})\end{array}$ & $\begin{array}{l}\text { Chlorophyll } \\
\text { content }\end{array}$ & $\begin{array}{l}\text { Leaf area }\left(\mathrm{cm}^{2}\right) \\
\text { SD1 }=80\end{array}$ & $\begin{array}{l}\text { No. of } \\
\text { tillers }\left(\mathrm{m}^{-2}\right)\end{array}$ & $\begin{array}{l}\text { Biological yield } \\
\left(\mathrm{kg} \mathrm{ha}^{-1}\right)\end{array}$ & $\begin{array}{l}\text { Grain yield } \\
\left(\mathrm{kg} \mathrm{ha}^{-1}\right)\end{array}$ \\
SD2 $=100$ & 86.258 & 10.988 & 51.767 & 32.194 & $259.58^{\mathrm{AB}}$ & $5500.0^{\mathrm{C}}$ & $1489.2^{\mathrm{C}}$ \\
SD3 $=120$ & 87.125 & 11.421 & 53.867 & 33.835 & $243.67^{\mathrm{B}}$ & $5750.0^{\mathrm{BC}}$ & $1587.5^{\mathrm{BC}}$ \\
SD4 $=140$ & 87.683 & 11.196 & 52.975 & 33.033 & $275.25^{\mathrm{AB}}$ & $6104.2^{\mathrm{AB}}$ & $1816.7^{\mathrm{AB}}$ \\
LSD at 5\% level & NS & 11.096 & 52.883 & 33.234 & $285.58^{\mathrm{A}}$ & $6437.5^{\mathrm{A}}$ & $1850.8^{\mathrm{A}}$ \\
\hline
\end{tabular}

$\underline{\text { Table 4: Interaction of nutrient ratios with seeding densities for biological yield }\left(\mathrm{kg} \mathrm{ha}^{-1}\right)}$

\begin{tabular}{|c|c|c|c|c|c|}
\hline \multirow[b]{2}{*}{ Nutrient ratio } & \multicolumn{4}{|c|}{ Seeding density } & \multirow[b]{2}{*}{ Mean } \\
\hline & SD1 80 & SD2 100 & SD3 120 & SD4 140 & \\
\hline$\overline{\mathrm{F} 1}=00$ & $5083.3^{\mathrm{B}}$ & $5416.7^{\mathrm{AB}}$ & $5000.0^{\mathrm{B}}$ & $5250.0^{\mathrm{AB}}$ & 5208.35 \\
\hline $\mathrm{F} 2=4530$ & $5166.7^{\mathrm{AB}}$ & $5583.3^{\mathrm{AB}}$ & $6333.3^{\mathrm{AB}}$ & $5833.3^{\mathrm{AB}}$ & 5708.3 \\
\hline $\mathrm{F} 3=9060$ & $5500.0^{\mathrm{AB}}$ & $5833.3^{\mathrm{AB}}$ & $6166.7^{\mathrm{AB}}$ & $7500.0^{\mathrm{A}}$ & 6250 \\
\hline $\mathrm{F} 4=13590$ & $6250.0^{\mathrm{AB}}$ & $6166.7^{\mathrm{AB}}$ & $6916.7^{\mathrm{AB}}$ & $7166.7^{\mathrm{AB}}$ & 6625.025 \\
\hline Means & 5500 & 5750 & 6104.175 & 6437.5 & \\
\hline LSD at $5 \%$ level & 2390.6 & & & & \\
\hline
\end{tabular}

Tahir et al. (2004) and Laghari et al. (2010), they reported that varying fertilizer regimes had significant impact on grain yield $\left(\mathrm{kg} \mathrm{ha}^{-1}\right)$ in wheat.

Seeding densities: Table 3 shows that varying seeding densities had no significant effect on plant height. The highest was noted in SD4 level, having $87.68 \mathrm{~cm}$, whereas the lowest was recorded in SD1 $(86.25 \mathrm{~cm})$. In Table 3, it was shown that varying seeding densities had no significant effect on spike length. The highest was noted in SD2 level, having $11.42 \mathrm{~cm}$, whereas the lowest was recorded in SD1 $(10.98 \mathrm{~cm})$. The varying seeding densities had no significant effect on chlorophyll contents. The highest was noted in SD2 level, having 53.86, whereas the lowest was recorded in SD1 (51.76). The varying seeding densities had no significant effect on leaf area. The highest was noted in SD2 level, having $33.83 \mathrm{~cm}^{2}$, whereas the lowest was recorded in SD1 $\left(32.19 \mathrm{~cm}^{2}\right)$. From Table 3, it was shown that varying seeding densities had significant effect on number of tillers $\mathrm{m}^{-2}$. The highest was noted in SD4 level, having 286, whereas the lowest was recorded in SD2 (244). These results are in agreement with the work of Shah et al. (2011), who reported that various seeding densities were significantly different for number of tillers $\mathrm{m}^{2}$ in wheat crop.

In Table 3, it was shown that varying seeding densities had significant effect on biological yield $\left(\mathrm{kg} \mathrm{ha}^{-1}\right)$. The highest was noted in SD4 level, having $6438 \mathrm{~kg} \mathrm{ha}^{-1}$, whereas the lowest was recorded in SD1 (5500). These results are in conferment with the work of Shah et al. (2011); they reported that various seeding densities were significantly different biological yield $\left(\mathrm{kg} \mathrm{ha}^{-1}\right)$ in wheat crop. In Table 3, it was shown that varying seeding densities had significant effect on grain yield. The highest was noted in SD4 level, having
$1851 \mathrm{~kg} \mathrm{ha}^{-1}$, whereas the lowest was recorded in SD1 (1489). These results agree with the work of Shah et al. (2011) and Hussain et al. (2010), they reported that various seeding densities were significantly different for number of grain yield $\left(\mathrm{kg} \mathrm{ha}^{-1}\right)$ in wheat crop.

Interactive effect of nutrient ratios with seeding densities: From the data given in Table 4, it was found that there was a significant interactive impact of various nutrient ratios to seeding densities for biological yield $\left(\mathrm{kg} \mathrm{ha}^{-1}\right)$. Maximum was recorded at F3×SD4 (7500) followed by F4 $\times$ SD4 (7166.7), whereas the minimum was noted in F1×SD1 (5083.3). These findings agree with those of Shah et al. (2011), they reported that there was significant effect of interactive influence of nutrient ratios with seeding densities.

Economic analysis: Economic analysis of wheat is calculated, using the data both for fertilizer and seed densities and, hence, benefit cost ratio is calculated from the same field trails data. The net returns of the data are calculated by the formula:

$$
\mathrm{NR}=\mathrm{TR}-\mathrm{TC}
$$

While, BCR was computed by the following formula:

$$
\mathrm{B} / \mathrm{C}=\mathrm{TR} / \mathrm{TC}
$$

Table 5 clearly explains the economic analysis of wheat, affected by the use of various fertilizer levels. In case of different ratio of fertilizer trials, maximum (8.45) BCR was recorded from the plots, in which $137 \mathrm{~kg} \mathrm{ha}^{-1}$ fertilizer was applied, whereas, minimum (2.28) BCR was noted with maximum use of $412.3 \mathrm{~kg} \mathrm{ha}^{-1}$. The data 
Sci. Technol. Dev., 35 (2): 82-87, 2016

\begin{tabular}{|c|c|c|c|c|c|c|c|c|c|}
\hline Sr. No. & $\begin{array}{l}\text { Fertilizer ratio } \\
\mathrm{N}: \mathrm{P}\left(\mathrm{kg} \mathrm{ha}^{-1}\right)\end{array}$ & $\begin{array}{l}\text { Grain yield } \\
\left(\mathrm{kg} \mathrm{ha}^{-1}\right)\end{array}$ & $\begin{array}{l}\text { Urea } \\
\left(\mathrm{kg} \mathrm{ha}^{-1}\right)\end{array}$ & $\begin{array}{l}\text { DAP } \\
\left(\mathrm{kg} \mathrm{ha}^{-1}\right)\end{array}$ & $\begin{array}{l}\text { Total fertilizer } \\
\left(\mathrm{kg} \mathrm{ha}^{-1}\right)\end{array}$ & $\begin{array}{l}\text { Value of } \\
\text { produce (Rs.) }\end{array}$ & $\begin{array}{l}\text { Cost of } \\
\text { fertilizer (Rs.) }\end{array}$ & $\begin{array}{l}\text { Net return } \\
\left(\text { Rs. ha }{ }^{-1}\right)\end{array}$ & BCR \\
\hline$\overline{\mathrm{F} 1}$ & $0-0$ & 1548.3 & 0 & 0 & 0 & 74318.4 & - & 74318.4 & - \\
\hline F2 & $45-30$ & 1642.5 & 72 & 65 & 137 & 78840.0 & 8340 & 70500.0 & 8.45 \\
\hline F3 & $90-60$ & 1840.8 & 145 & 130.3 & 275.3 & 88358.4 & 16745.2 & 71613.2 & 4.28 \\
\hline $\mathrm{F} 4$ & $135-90$ & 1712.5 & 217 & 195.3 & 412.3 & 82200.0 & 25085.2 & 57114.8 & 2.28 \\
\hline
\end{tabular}

Table 6: Benefit cost ratio (BCR) for seed densities in wheat under late sowing conditions

\begin{tabular}{lccccc}
\hline Seed density $\left(\mathrm{kg} \mathrm{ha}^{-1}\right)$ & Grain yield $\left(\mathrm{kg} \mathrm{ha}^{-1}\right)$ & Value of produce (Rs.) & Cost of seed (Rs.) & Net return (Rs.) & BCR \\
\hline SD1 $=80$ & 1489.2 & 71481.6 & 3840 & 67641.6 & 71400.0 \\
SD2 $=100$ & 1587.5 & 76200.0 & 4800 & 81441.6 & 14.875 \\
SD3 $=120$ & 1816.7 & 87201.6 & 5760 & 82118.4 & 14.13917 \\
SD4 $=140$ & 1850.8 & 88838.4 & 6720 & 12.22 \\
\hline
\end{tabular}

further revealed that the use of fertilizer in delayed sown conditions was non-significant due to late rains. Moreover, it was also observed that wheat sowing after soybean (Glycine max L.) does not need much fertilizer and, in this case, the impact of nutrient ratios may be at par due to residual nitrogen prevalence in rhizosphere as nitrogen enhanced vegetative growth. Hence legumes must be included in cropping systems of wheat rotation in order to save fertilizer costs.It is clear from the data, given in Table 6, that when plots were seeded with $140 \mathrm{~kg} \mathrm{ha}^{-1}$, they produced maximum (Rs. 82118.4) net returns, while plots in which seed rate was used at $80 \mathrm{~kg} \mathrm{ha}^{-1}$, a minimum (Rs. 67641.6) net return was noted. The data also revealed that BCR was higher when seed rate was applied at $80 \mathrm{~kg} \mathrm{ha}^{-1}$ and gave (17.61) BCR, when plots were seeded with $140 \mathrm{~kg} \mathrm{ha}^{-1}$, then (12.22) BCR is minimum.

\section{CONCLUSION}

Rain fed crop production is a high risk task in Pakistani conditions when coupled with changing climatic conditions, increasing prices of seeds and fertilizers. For wheat crop, which is our staple food crop, a study was executed to investigate optimum seeding densities and nutrient ratios in order to get high returns in late sown conditions. From the analyzed data, it was revealed that there were 22 and $21 \%$ higher tillers $\mathrm{m}^{-2}$ and biological yield $\left(\mathrm{kg} \mathrm{ha}^{-1}\right)$ as compared to those conditions when there was no fertilizer application in the soil. Moreover, there was $16 \%$ increment in grain yield but it was statistically at par. In case of various seeding densities, $140 \mathrm{~kg} \mathrm{ha}^{-1}$ proved the best option for tillers $\mathrm{m}^{-2}$, biological yield and grain yield $\left(\mathrm{kg} \mathrm{ha}^{-1}\right)$. When interactive effect was considered, it was shown that (90 $60 \mathrm{NP} \mathrm{kg} \mathrm{ha}{ }^{-1}$ )×140 $\mathrm{kg} \mathrm{ha}^{-1}$ seeding density produced the maximum biological yield in late sown conditions (7500), which was 32\% higher as compared to no nutrient ratio $\times 80 \mathrm{~kg} \mathrm{ha}^{-1}$ seeding density. In case of fertilizer maximum BCR is (8.45) at $137 \mathrm{~kg} \mathrm{ha}^{-1}$ and incase of seed densities maximum BCR is (17.61) at $80 \mathrm{~kg} \mathrm{ha}^{-1}$. It is clear from the above data that in delayed cropping, various nutrient ratios were at par for grain yield and ideal results can be achieved only when breeding behavior of newly developed cultivar must be tested in normal and late sowing conditions.

\section{REFERENCES}

Ahmad, I., M. Jamil, M.H. Zia and A. John, 1999. Nitrogen management for wheat production through integrated plant nutrition system. Pak. J. Soil Sci., 17: 59-64.

Ahmad, N., M.T. Saleem and I.T. Twyford, 1992. Phosphorus research in Pakistan: A review. Proceedings of the Symposium on the Role of Phosphorus in Crop Production, July 15-17, 1992, Islamabad, Pakistan, pp: 59-92.

Akhtar, M., S.A. Randhawa, M.T. Mahmood and Ehsan Ullah, 1999. Interactive effect of nitrogen and phosphorus on agronomic traits of maize (Zea mays L.). Int. J. Agric. Biol., 1: 334-336.

Ali, H., H.A. Randhawa and M. Yousaf, 2004. Quantitative and qualitative traits of sunflower (Helianthus annuus L.) as influenced by planting dates and nitrogen application. Int. J. Agric. Biol., 6: 410-412.

Gill, M.A., Rahmatullah and M. Salim, 1994. Growth responses of twelve wheat cultivars and their phosphorus utilization from rock phosphate. J. Agron. Crop Sci., 173: 204-209.

GoP., 2014-15. Economic survey. Finance Division, Economic Advisor's Wing, Government of Pakistan, Islamabad, Pakistan.

Hameed, E., W.A. Shah, A.A. Shad, J. Bakht and T. Muhammad, 2003. Effect of different planting dates, seed rate and nitrogen levels on wheat. Asian J. Plant Sci., 2: 467-474.

Harper, J.L., 1977. Population Biology of Plants. 1st Edn., Academy Press, London, ISBN-13: 978-0123258502, pp: 41-54. 
Hussain, I., M.A. Khan and H. Khan, 2010. Effect of seed rates on the agro-physiological traits of wheat. Sarhad J. Agric., 26: 169-176.

Jabbar, A., T. Aziz, I.H. Bhatti, Z.A. Virk, M.M. Khan and Wasl-u-Din, 2009. Effect of potassium application on yield and protein contents of late sown wheat (Triticum aestivum L.) under field conditions. Soil Environ., 28: 193-196.

Kabesh, M.O., M.F. El-Kramany, G.A. Sary, H.M. El-Naggar and S.H.B. Gehan, 2009. Effects of sowing methods and some bio-organic fertilization treatments on yield and yield components of wheat. Res. J. Agric. Biol. Sci., 5: 97-102.

Khan, I.A., J. Bakht, W.A. Shah, N. Khan and I. Ullah, 2002. Effect of seed rate on the yield and yield components of wheat under irrigated conditions of Peshawar. Asian J. Plant Sci., 1: 513-515.

Laghari, G.M., F.C. Oad, S. Tonio, A.W. Gandahi, M.H. Siddique, A.W. Jagirani and S.M. Oad, 2010. Growth, yield and nutrient uptake of various wheat cultivars under different fertilizer regimes. Sarhad J. Agric., 26: 489-497.

Malghani, A.L., A.U. Malik, A. Sattar, F. Hussain, G. Abbas and J. Hussain, 2010. Response of growth and yield of wheat to NPK fertilizer. Sci. Int., 24: 185-189.

Marschner, H., 1995. Mineral Nutrition of Higher Plants. 2nd Edn., Academic Press Ltd., London, UK., ISBN-13: 978-0124735439, pp: 48-173.

Mazurek, J. and J. Kus, 1991. Effect of nitrogen fertilizer application and sowing date and rate on yield and quality of grain of spring wheat cultivars grown after different preceding crops. Biol. Inst. Hodowli Aklimatyzaeji Roslin, 177: 123-136.
Memon, K.S., 1996. Soil and Fertilizer Phosphorus. In: Soil Science, Bashir, E. and R. Bantel (Eds.). National Book Foundation, Islamabad, pp: 291-316.

Nakano, H. and S. Morita, 2009. Effects of seeding rate and nitrogen application rate on grain yield and protein content of the bread wheat cultivar Minaminokaori in Southwestern Japan. Plant Prod. Sci., 12: 109-115.

Niamatullah, M., M. Khan, M.Q. Khan, M. Sadiq, K.U. Zaman, C.S. Hayat and S. Rehman, 2011. Impact of NPK applications on the number of productive tillers and cost benefit analysis of wheat in hill-torrent irrigated area of D.I. Khan Division, Khyber Pakhtunkhwa. J. Anim. Plant Sci., 21: 211-214.

Novoa, R. and R.S. Loomis, 1981. Nitrogen and plant production. Plant Soil, 58: 177-204.

Shah, W.A., H.U. Khan, S. Anwar and K. Nawab, 2011. Yield and yield components of wheat as affected by different seed rates and nitrogen levels. Sarhad J. Agric., 27: 17-25.

Slafer, G.A. and E.H. Satorre, 1999. An Introduction to the Physiological-Ecological Analysis of Wheat Yield. In: Wheat: Ecology and Physiology of Yield Determination, Satorre, E.H. and G.A. Slafer (Eds.). CRC Press, USA., ISBN: 9781560228745, pp: 3-12.

Steel, R.G.D., J.H. Torrie and D.A. Deekey, 1997. Principles and Procedures of Statistics: A Biometrical Approach. 3rd Edn., Mc Graw Hill, New York, ISBN: 9780070610286, pp: 400-428.

Tahir, M., M.A. Ali, S. Iqbal and M. Yamin, 2004. Evaluation of the effect of use of NP fertilizer in different ratios on the yield of wheat (Triticum aestivum) crop. Pak. J. Life Soc. Sci., 2: 145-147. 